\title{
Movement patterns and spawning activity of individual nase Chondrostoma nasus (L.) in flow-regulated and weir-fragmented rivers
}

\author{
By M. Ovidio and J. C. Philippart \\ Biology of Behaviour Unit, Laboratory of Fish Demography and Hydroecology, University of Liège, Tihange, Belgium
}

\begin{abstract}
Summary
Eighteen adult nase Chondrostoma nasus (L.) $(37.6-48.2 \mathrm{~cm}$ FL) from three highly fragmented Belgian rivers were tagged with surgically implanted radio transmitters and manually tracked from the banks of the rivers for 3-34 weeks. Their movements were mainly recorded during the circum reproduction period in 2001, 2002 and 2006 in river stretches delimited by physical barriers and/or minimum flow conditions. To reach the spawning grounds, nase displayed different patterns of movements that were mainly influenced by the configuration of the study site, the date of observation and the associated environmental conditions. Nase never cleared any physical obstacle but were able to spawn in minimum flow conditions or just downstream from physical obstacles. Nase were present on spawning grounds in late March in the warmest spring (2001) and from midApril to early May in the coldest spring (2006). After spawning, a major proportion of $C$. nasus migrated a substantial distance downstream, whereas others remained near their capture site and showed frequent movements, sometimes corresponding to group displacements from one river to another.
\end{abstract}

\section{Introduction}

In European rivers, cyprinids play a major role in riverine ecosystems because of their high abundance (Philippart, 1981; Mann and Penczak, 1986). Their variety of life-history patterns and habitat requirements make cyprinids good indicators of the ecological quality and the structural properties of river systems (Keckeis et al., 1996). The increasing structural changes in many river systems were accompanied by a drastic decline in lithophilic cyprinids (Keckeis et al., 1996; Peňáz, 1996; Nelva, 1997; Lusk et al., 2004). The nase (Chondrostoma nasus) is an indicator species for habitat quality in the lower rhithral and upper potamal zones of European river systems and was one of the most affected species (Nelva, 1997). Decline in their populations was mainly caused by construction of dams for a hydroelectric power plant together with the straightening and artificialization of the river banks (Zbinden and Maier, 1996). Moreover, in the major part of its distribution area, nase was also affected by changes in hydrobiological regimes, changes in riverbed morphology at spawning times, persisting water pollution and reduction in food resources (Peňáz, 1996).

Despite the critical state of nase populations in many European rivers, little information exists on its life history and behavioural ecology. Information on individual behaviour, mobility and spawning migrations are extremely limited
(Huber and Kirchhofer, 1998). In order to improve protection of the species and to better understand nase sensitivity to the degradation of its environment, knowledge on its space and time utilization in a wide range of disturbed and less disturbed river typologies is urgently required.

The objectives of this paper were to (i) analyse the mobility patterns of individual nase during the reproduction period, (ii) identify the environmental cues that triggered their migration and spawning activity, (iii) localize spawning areas in different river configurations and (iv) evaluate the impact of the river fragmentation and minimum flow conditions on $C$. nasus reproductive biology and use of space. The study was conducted using radio-telemetry in three different rivers of southern Belgium.

\section{Materials and methods}

Nase ( $C$. nasus) were studied in three different rivers of the Meuse basin (Fig. 1, Table 1): the Ourthe (tributary of the Meuse), the Vesdre (tributary of the Ourthe) and the Amblève (tributary of the Ourthe). Eighteen adults were captured by boat DC electric fishing (DEKA, 2.5kVA). In the Ourthe, $\mathrm{n}=5$ nase were captured in late February and early March 2001 in a river stretch physically limited by obstacles D and E (Fig. 1). In the Vesdre, $n=7$ nase were captured in early February and March 2002 (Table 2) downstream from physical obstacle A (Fig. 1) in a river stretch situated in the confluence area between the River Vesdre and the River Ourthe and physically limited by obstacles A, B and C. In the Amblève, $n=6$ nase were captured in early March 2006 in a river stretch influenced by both minimum flow conditions (set at $3 \mathrm{~m}^{3} \mathrm{~s}^{-1}$ for a mean annual discharge of $22 \mathrm{~m}^{3} \mathrm{~s}^{-1}$ ) and physical obstacles $F$ and $G$ (intake weir of a hydroelectric power plant) (Fig. 1). Obstacles A, B and E that may potentially block the upstream movements of nase are presented in Fig. 2 The obstacle $G$ is an insurmountable obstacle.

Nase were anaesthetized in a solution of 2-phenoxy-ethanol $\left(0.2 \mathrm{mg} \mathrm{l}^{-1}\right)$, and a radio transmitter (ATS Inc., $40 \mathrm{MHz}$, trailing whip antenna) was inserted into the body cavity of the fish through a midventral incision (Ovidio and Philippart, 2002). The sex of the nase was determined by visual inspection of the gonads through the incision that was closed by three separate stitches, using sterile, resorbable, plain Vicryl sutures. In order to avoid any adverse effect of longterm post-operative care on their behaviour, nase were released at their exact capture site as soon as they had recovered and showed spontaneous swimming activity (approximately 20-30 min after surgery). Locations were 

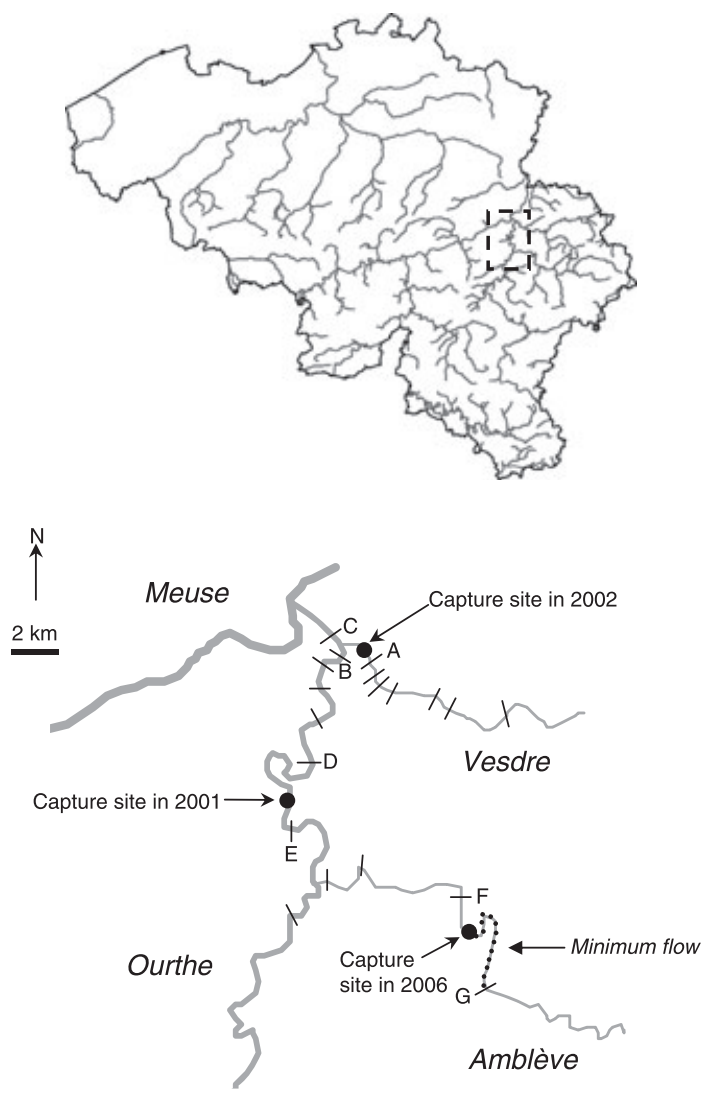

Fig. 1. Locations of the study sites in Belgium. Bars across the river represent physical obstacles. Obstacles cited in the paper are labelled from $A$ to $G$

Table 1

Main characteristics of three rivers where nase (Chondrostoma nasus) were radio-tracked

\begin{tabular}{lccc}
\hline Characteristics & Ourthe & Vesdre & Amblève \\
\hline Elevation source $(\mathrm{m})$ & 507 & 626 & 586 \\
Length $(\mathrm{km})$ & 175 & 72 & 135 \\
Drainage area $\left(\mathrm{km}^{2}\right)$ & 3672 & 702 & 1083 \\
Average slope $\left(\mathrm{m} \mathrm{l}^{2} 000 \mathrm{~m}^{-1}\right)$ & 2.54 & 7.8 & 5.20 \\
Within lower course $(\mathrm{m})$ & $30-60$ & $30-50$ & $30-50$ \\
Average annual discharge $\left(\mathrm{m}^{3} \mathrm{~s}^{-1}\right)$ & 67.4 & 11.4 & 21.7 \\
Mean temperature in July $\left({ }^{\circ} \mathrm{C}\right)$ & 19.9 & 19.4 & 17.1 \\
Dominant Huet $(1949)$ fish zone & Barbel & Barbel & Grayling \\
Dominant fish species (kg) & Barbel & Gudgeon & Barbel \\
Level of global water quality & High & Medium & High \\
Level of fragmentation & Medium & High & Medium \\
\hline
\end{tabular}

made by triangulation from markers on the banks of the rivers, using mobile FieldMaster radio receivers and loop antennas (ATS Inc.). Locations were made during daytime, with accuracy between 5 and $20 \mathrm{~m}^{2}$, depending on the distance between the fish and the observer and the width of the river. Tracking started the day after tagging. Fish were located from 3 to 7 days a week. Water temperature was recorded hourly by data loggers (TidBit; Onset Computer Corp.) and water flow was continually monitored (data from the Water Division) in each river.

\section{Results}

\section{Movements in the River Ourthe}

Except for small scale excursions of nase $\mathrm{O} 2, \mathrm{O} 3$ and $\mathrm{O} 5$ in March 2001, all individuals showed restricted mobility near their capture area until mid-March (Fig. 3). On 19 and 22 March, nase O1, O4 and O5 started moving downstream during high flood conditions and when the mean daily water temperature increased, varying from 7 to $8.5^{\circ} \mathrm{C}$. Nase $\mathrm{Ol}, \mathrm{O} 4$ and $O 5$ were lost on 21 and 23 March $4.2,4.3$ and $9 \mathrm{~km}$, respectively, downstream from their capture area. Nase $\mathrm{O} 3$ also moved downstream on 19 March $(1.4 \mathrm{~km})$ but homed to its capture site on 20 March and then moved again $1.4 \mathrm{~km}$ downstream on 21 March 2001. From 22 to 29 March, during very high flood events and decreasing water temperature, nase $O 3$ frequently moved several hundred meters in up- and downstream directions. On 30 March 2001, during increasing water temperature $\left(7^{\circ} \mathrm{C}\right)$ and high but decreasing flood conditions, nase $\mathrm{O} 3$ gradually moved downstream and was finally lost on 8 April 2001, approx. $8 \mathrm{~km}$ downstream from its capture site. Nase $O 2$ showed highly restricted mobility (daily movements of max. $300 \mathrm{~m}$ ) until 9 April 2001. On 12 April 2001, during a second high flood event, nase O2 moved $2.2 \mathrm{~km}$ upstream, remaining there until the end of the 2001 tracking session (26 April 2001). In the Ourthe, the distances travelled between successive locations were statistically greater when the river flow exceeded $90 \mathrm{~m}^{3} \mathrm{~s}^{-1}$ than during other flow conditions (Scheffe $f$-test, $\mathrm{P}<0.001$ ).

\section{Movements in the River Vesdre}

In late winter, during high flood and low water temperature conditions, nase frequently moved between two locations, but were never located more than $1 \mathrm{~km}$ downstream from obstacle A (Fig. 4). In late March during a substantial increase in water temperature and during decreasing flow conditions, the tagged nase were mainly located in the upper part of the study reach (near obstacle A) and spawning activity was observed in the vicinity of obstacle A from 25 to 30 March 2002, when the mean daily water temperature varied from 9 to $12^{\circ} \mathrm{C}$.

During the post-spawning period, nase $V 1, V 2$ and $V 3$ stayed in the downstream vicinity of obstacle $A$ in the Vesdre until 3 June 2002, then moved together to the River Ourthe, downstream from obstacle B, remaining there until midOctober. Nase V4 stayed near its capture site until 8 July 2002, then frequently moved from the River Vesdre to the River Ourthe (between physical obstacles A and B; Figs 1 and 2) until mid-October 2002. Nase V5 and V7 moved downstream in late March and late April, approx. 3 and $1.5 \mathrm{~km}$ from their capture site. Nase $V 7$ probably died after spawning, as the transmitter was found in the river. Nase V5 was lost during its downstream migration. Nase $V 6$ was found in the River Meuse, roughly $6 \mathrm{~km}$ from its capture site, then regularly moved up and down between two resting places separated by roughly $2 \mathrm{~km}$. Data analysis suggested that nase movements were not statistically triggered by specific environmental conditions. For nase $V 1, V 2, V 3, V 6$ and $V 7$, distances travelled after the spawning season were higher than those travelled before spawning (Scheffe $f$-test, $\mathrm{P}<0.05$ ).

\section{Movements in the River Amblève}

Nase A1, A3, A4 and $A 5$ showed restricted mobility from 3 March to 13 April 2006, as the distance between successive locations rarely exceeded $300 \mathrm{~m}$ despite high flood events in mid-March. From 16 to 24 April, during decreasing flow and increasing water temperature ranging from 8.5 to $12.5^{\circ} \mathrm{C}$, they moved to a spawning area located in minimum flow conditions, approx. $1.3 \mathrm{~km}$ upstream from their capture site and 


\begin{tabular}{|c|c|c|c|c|c|c|c|}
\hline $\begin{array}{l}\text { Fish } \\
\text { number }\end{array}$ & River & $\begin{array}{l}\text { Fork } \\
\text { length }\end{array}$ & Weight & Sex & Capture date & End of tracking & $\begin{array}{l}\text { Weeks } \\
\text { tracked }\end{array}$ \\
\hline $\mathrm{O} 1$ & Ourthe & 461 & 1600 & $\mathrm{~F}$ & 22 Feb. 2001 & 21 Mar. 2001 & 4 \\
\hline $\mathrm{O} 2$ & Ourthe & 436 & 1376 & $\mathrm{~F}$ & 6 Mar. 2001 & 26 Apr. 2001 & 11 \\
\hline O3 & Ourthe & 432 & 1225 & M & 6 Mar. 2001 & 8 Apr. 2001 & 5 \\
\hline $\mathrm{O} 4$ & Ourthe & 440 & 1410 & $\mathrm{M}$ & 6 Mar. 2001 & 23 Mar. 2001 & 3 \\
\hline O5 & Ourthe & 442 & 1543 & $\mathrm{~F}$ & 6 Mar. 2001 & 23 Mar. 2001 & 3 \\
\hline V1 & Vesdre & 400 & 960 & $\mathrm{~F}$ & 7 Feb. 2002 & 4 Oct. 2002 & 34 \\
\hline $\mathrm{V} 2$ & Vesdre & 386 & 948 & $\mathrm{~F}$ & 7 Feb. 2002 & 12 Sept. 2002 & 31 \\
\hline V3 & Vesdre & 412 & 1104 & $\mathrm{~F}$ & 7 Feb. 2002 & 21 Aug. 2002 & 28 \\
\hline V4 & Vesdre & 396 & 976 & $\mathrm{M}$ & 6 Mar. 2002 & 27 Oct. 2002 & 34 \\
\hline V5 & Vesdre & 376 & 768 & M & 6 Mar. 2002 & 29 Mar. 2002 & 3 \\
\hline V6 & Vesdre & 436 & 1290 & $\mathrm{M}$ & 6 Mar. 2002 & 11 June 2002 & 14 \\
\hline V7 & Vesdre & 426 & 1211 & $\mathrm{~F}$ & 6 Mar. 2002 & 10 May 2002 & 9 \\
\hline Al & Amblève & 465 & 1696 & $\mathrm{~F}$ & 3 Mar. 2006 & 31 May 2006 & 13 \\
\hline A2 & Amblève & 482 & 1527 & $\mathrm{M}$ & 3 Mar. 2006 & 31 May 2006 & 13 \\
\hline A3 & Amblève & 490 & 2142 & $\mathrm{~F}$ & 5 Mar. 2006 & 31 May 2006 & 13 \\
\hline A4 & Amblève & 430 & 1634 & $\mathrm{M}$ & 5 Mar. 2006 & 31 May 2006 & 13 \\
\hline A5 & Amblève & 448 & 1327 & $\mathrm{M}$ & 5 Mar. 2006 & 31 May 2006 & 13 \\
\hline A6 & Amblève & 474 & 1693 & $\mathrm{~F}$ & 5 Mar. 2006 & 31 May 2006 & 13 \\
\hline
\end{tabular}

Table 2

Characteristics of 18 radio-tracked nase (Chondrostoma nasus)
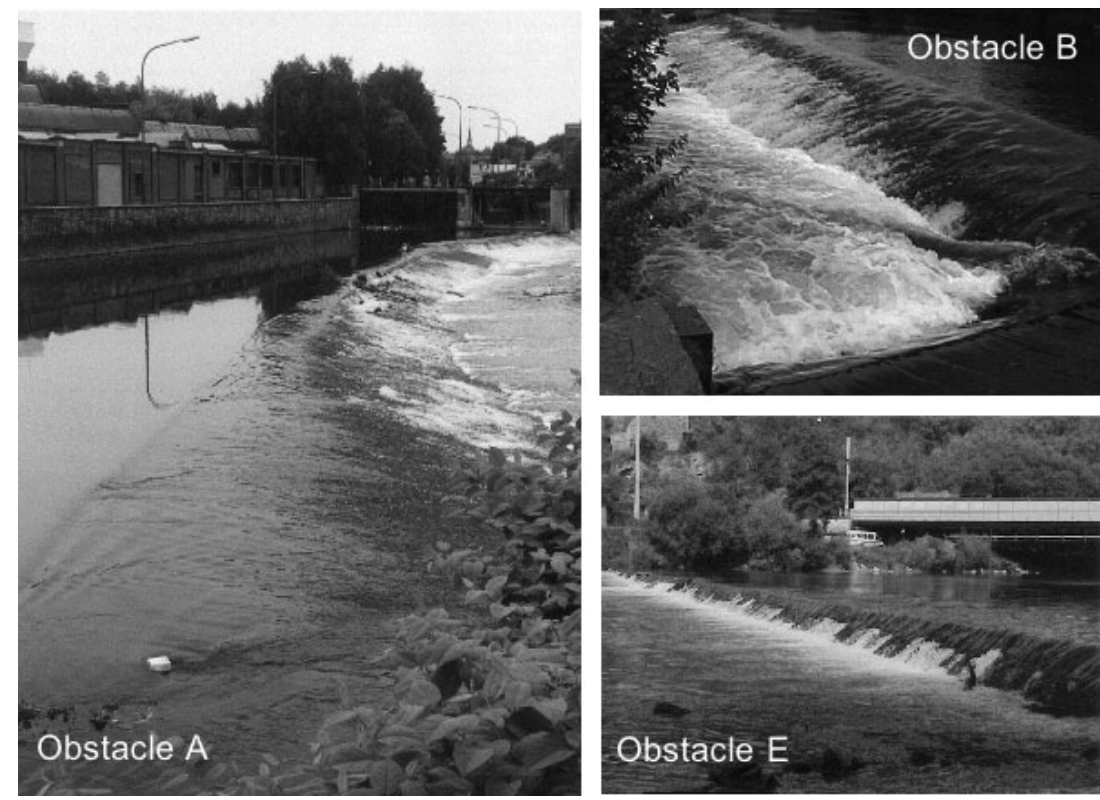

Fig. 2. Obstacles that may potentially interfere with the free upstream movements of nase (letters refer to a geographical position, figure 1)

stayed there from 6 to 15 days (Fig. 5). Afterwards, nase A4 kept on an upstream migration to another spawning area located roughly $2.6 \mathrm{~km}$ upstream from its capture site (and was located in the same area as nase A6). After spawning activity, nase $A 4$ finally moved downstream from 30 April to 8 May 2006. Nase A3, $A 4$ and $A 5$ went back to the same site situated approx. $1.5 \mathrm{~km}$ from their capture site and stayed there until the end of the tracking period. Nase Al showed a similar behaviour $1.4 \mathrm{~km}$ downstream. Nase A6 showed greater mobility from early March to early April, as it frequently moved more than $500 \mathrm{~m}$ from one location to another. On 12 April when the mean daily water temperature reached $7.5^{\circ} \mathrm{C}$ for the first time in the year, nase $A 6$ moved roughly $3.9 \mathrm{~km}$ upstream to a spawning area located in minimum flow conditions, remaining there until 5 May 2006, then moving $3.7 \mathrm{~km}$ downstream in 5 days; nase A6 remained in this place until 22 May, then progressively moved approx. $8 \mathrm{~km}$ downstream from its capture site. Nase A2 moved roughly $2 \mathrm{~km}$ downstream just after tagging and remained in the same area until 12 April when it reached a spawning site located roughly $4 \mathrm{~km}$ from its capture site; here, Nase $A 2$ stayed until 6 May 2006, but no spawning events were observed in this area. It finally moved $4 \mathrm{~km}$ downstream in early May after the spawning season. Nase movements in the Amblève River were greatest in the $7-15^{\circ} \mathrm{C}$ water temperature intervals. A significant difference in the weekly mean distance travelled was observed when grouping the distances travelled between successive locations into three categories of water temperature $\left(<7^{\circ} \mathrm{C} ; \quad 7-15^{\circ} \mathrm{C} ; \quad>15^{\circ} \mathrm{C} ; \quad\right.$ Kruskal-Wallis, $\mathrm{P}<0.001)$.

\section{Discussion}

This study provided original observations on nase (C. nasus) mobility and spawning activity in three different rivers characterized by a high level of human disturbance. Studied individuals were radio-tagged using surgical implantation. This method has several advantages over external attachment, including avoidance of vegetation entanglement, as well as less interference with swimming behaviour and speed (Winter, 1983; Mellas and Haynes, 1985; Jepsen et al., 2002). In our study area, the utilization of trailing whip antenna was necessary to increase the power of the signal. The susceptibility to complications with such transcutaneous devices in tagged 


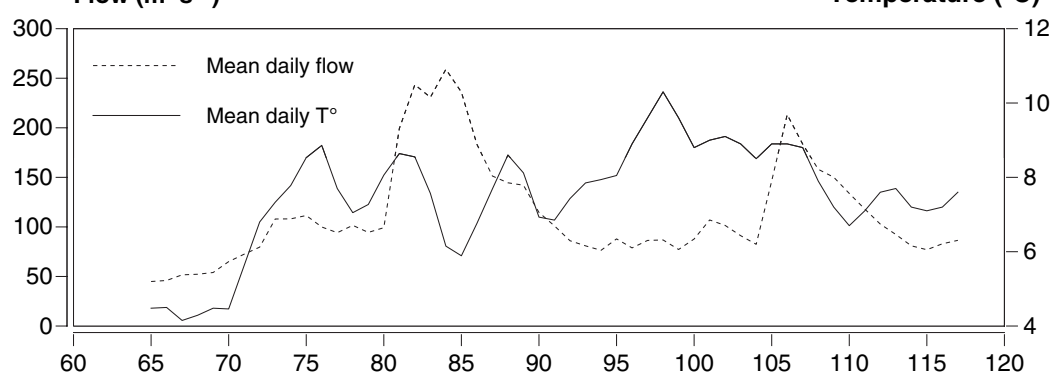

Fig. 3. Variations in water level and mean daily water temperature in the River Ourthe (upper graph) and positions of the radio-tagged nase (lower graph) during the study in 2001. The location point "zero" corresponds to the capture site of most individuals

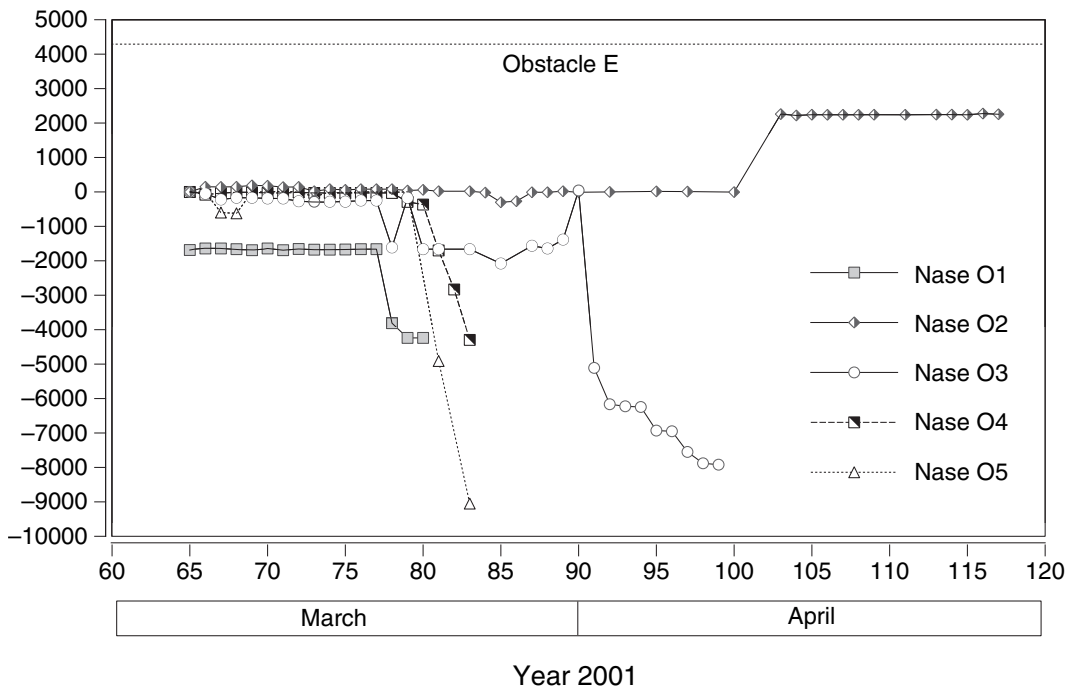

As already questioned for the roach Rutilus rutilus in the Belgian Meuse and Scheldt basins (Geeraerts et al., 2007), our observations suggest that nase are not frequent obstacle leapers and that they move relatively short distances to spawn in the rivers investigated. Nevertheless, it is still difficult to state whether this is because they are unable to clear barriers or because the abundance of appropriate spawning areas in the rivers studied (Philippart, 1981) did not force them to move further upstream. Frequent captures of nase in Denil traps and basin fish passes in the main course of the canalized River Meuse (J. C. Philippart and M. Ovidio, unpubl. data) and Rhine (Iffezheim fish pass, unpubl. data) demonstrated that they are at least able to pass such artificial devices when spawning grounds are not available in the vicinity. Furthermore, Lusk (1967), Lampert and Link (1971), Povz (1988), Huber and Kirchhofer (1998) and Mercier (2001) have also recorded extreme movements (from tens of kilometres to more than $100 \mathrm{~km}$ ) in the Danube, Rhine, Sava and Meuse basins in intensive tag-recapture experiments, suggesting that nase may nevertheless move much greater upstream distances in some instances. Thus, even if the nase seems sometimes able to survive in a sporadic way and to spawn despite substantial river fragmentation (Prokes and Barus, 1995), efficient fish passes may help them to progressively recolonize longer river stretches and may prevent the genetic degeneration of local populations.

\section{Spawning activity}

The timing of the spawning period varied from 1 year to another. In the warmest spring (2002), spawning was observed
(Switzerland), where nase spawned just downstream frome physical obstacles.

\section{.

.

(1)



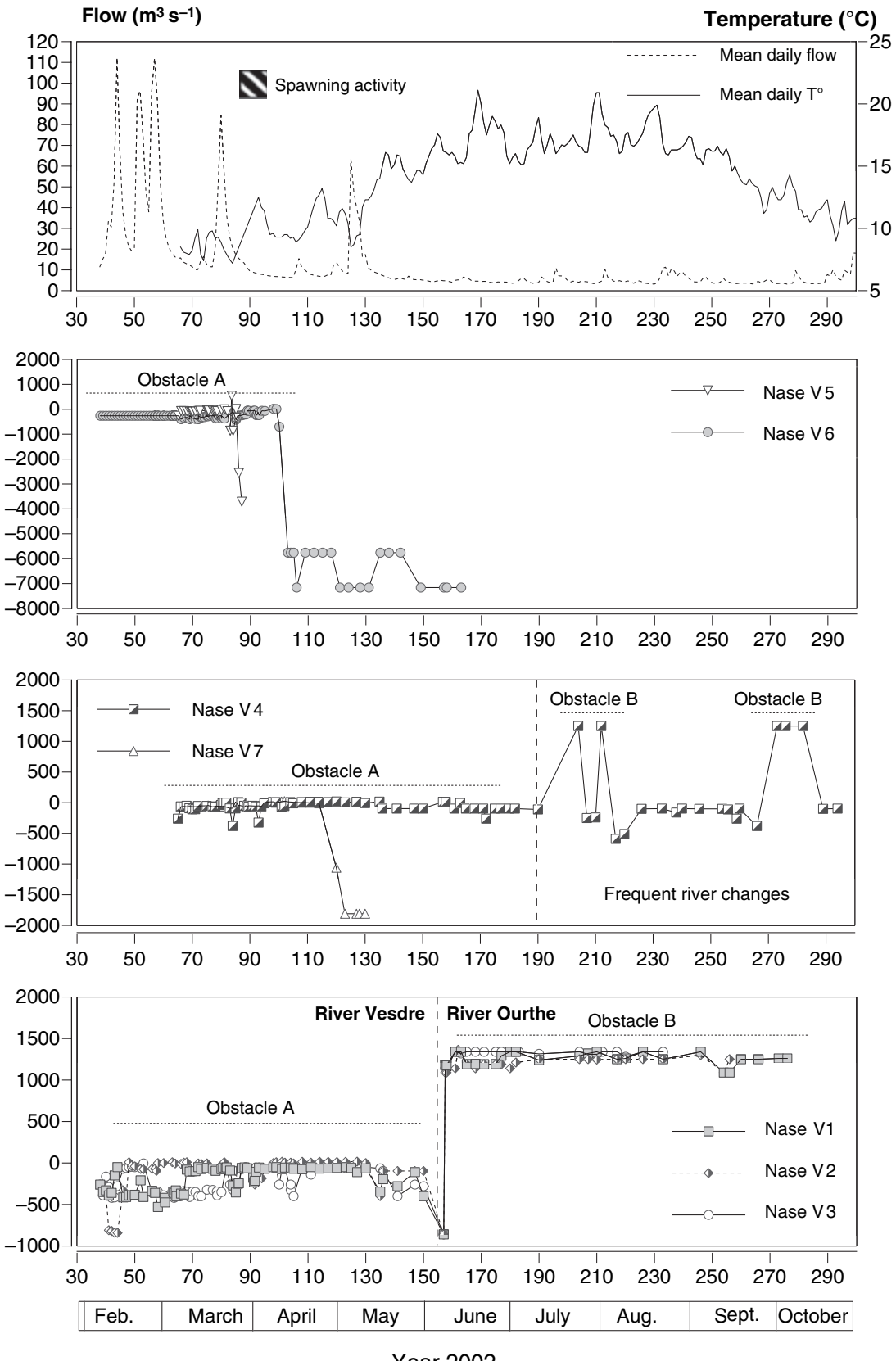

Year 2002
Fig. 4. Variations in water level and mean daily water temperature in the River Vesdre (upper graph) and positions of the radio-tagged nase (lower graph) during the study in 2002 . The location point "zero" corresponds to the capture site of most individuals from 25 to 30 March, whereas in the coldest spring (2006), spawning only occurred between 16 April and 3 May. Spawning occurred in shallow gravel bed habitats with strong current when the mean daily water temperature varied from 7.5 to $14^{\circ} \mathrm{C}$. No apparent differences were observed between tagged males and females concerning the arrival date and the time spent on spawning grounds. In the Brumokva River (Czech Republic), Lelek and Peňáz (1963) observed that spawning started at a water temperature of $8^{\circ} \mathrm{C}$, attaining its maximum around the peaks of daily temperature $\left(15.4^{\circ} \mathrm{C}\right)$ between 13.00 and 15.00 in the afternoon. A greater number of males was found to spawn with only one female. Keckeis et al. (1996) observed spawning of nase in the main channel of the Danube. Compared with spawning migration into tributaries, they suggested that this may be a part of a new behaviour induced by canalizing rivers and cutting off side-arms. The highest abundance of spawners was correlated with uniform gravel banks which have relatively steep slopes (coarse substrata and high currents) (Keckeis et al., 1996). In Switzerland, all identified nase spawning grounds were also situated in shallow water with a gravel bed and high water velocity, but the main spawning events lasted only 2-3 days (Zbinden and Maier, 1996). In the past, spawning schools were often made up of several thousand individuals, sometimes more than 10 000. After 1993, a considerably smaller number of spawners was observed, often consisting of fewer than 50 individuals (Zbinden and Maier, 1996). In the Amblève, the tagged nase left their capture site in natural flow conditions to spawn just upstream in minimum flow conditions. The effects of minimum flow conditions on the spawning ecology of cyprinids are poorly known. However, at the same study site, M. Ovidio and J. C. Philippart (unpubl. data) demonstrated that, contrary to the nase, barbel (Barbus barbus) radio-tagged at the same place unusually migrated in the downstream direction to spawn, probably to avoid minimum flow conditions. This behavioural difference is probably related to the 
Fig. 5. Variations in water level and mean daily water temperature in the River Amblève (upper graph) and posigraph) during the study in 2006 . The location point "zero" corresponds to the limit between the natural and the minimum flow tions of the radio-tagged nase (lower
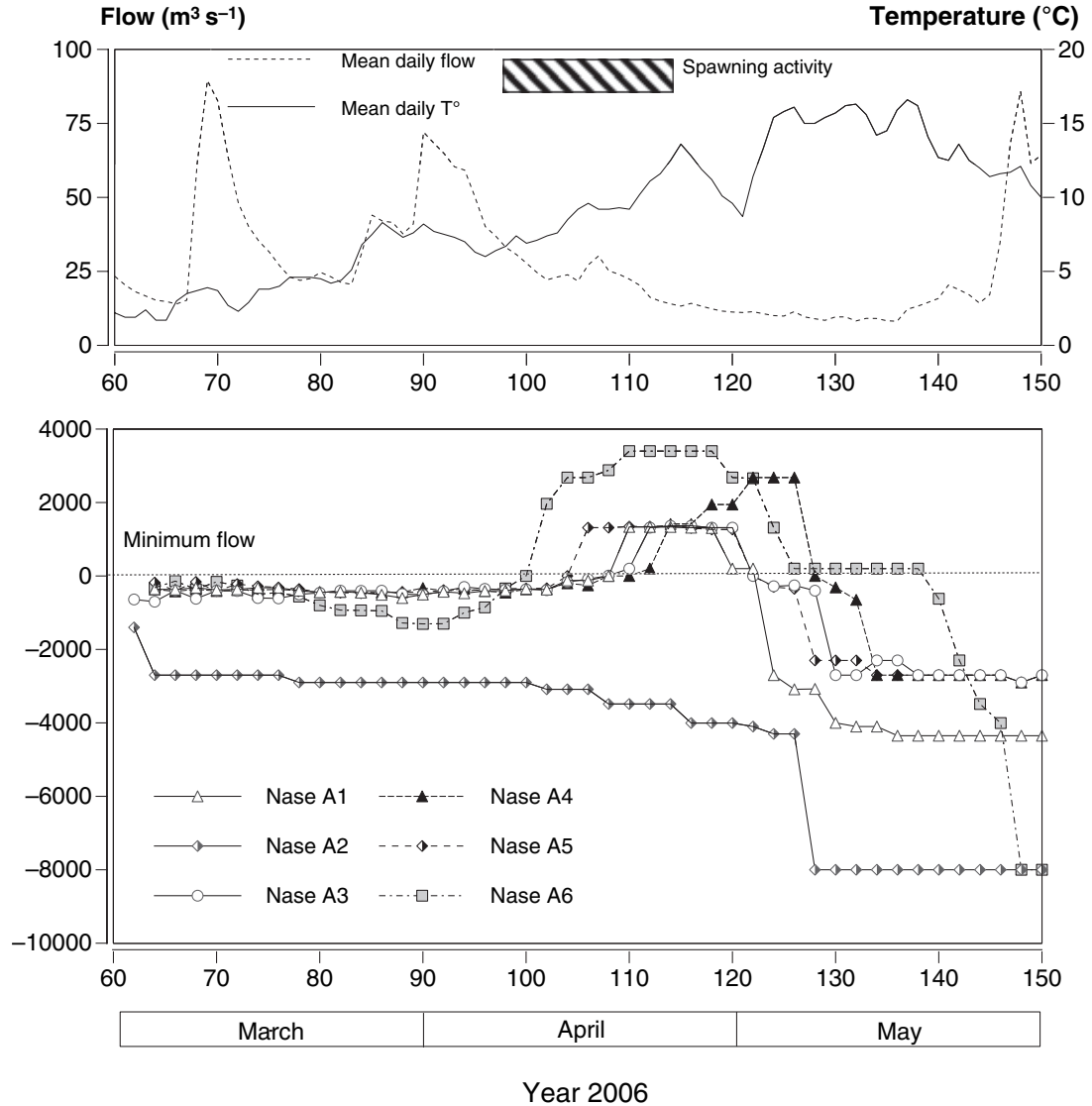

fact that the barbel spawns under the gravel bed, whereas the nase spawns on the surface of the gravel bed; the latter is therefore influenced by deposits of fine materials that cause a decrease in the oxygenation of the lower layers of the substratum in the sector bypassed in minimum flow (Guillaume, 2006). Furthermore, by spawning in minimum flow conditions, the nase eggs have a lesser chance of being washed away by high flow conditions. These may reflect distinct adaptive changes in behavioural strategies between the two species after the surrounding milieu has been disturbed.

\section{Post-spawning movements}

In our study, post-spawning activity of tagged nase was characterized by a clear tendency to move several kilometres downstream, both in individuals that migrated upstream to reproduce and those that did not actually migrate before spawning and reproduced in the vicinity of a physical obstacle. Similar observations were made in the River Aare in Switzerland where nase dispersed over a greater area after spawning (Huber and Kirchhofer, 1998). Post-spawning downstream movements are frequent in freshwater fish (e.g. Salmo trutta, Thymallus thymallus, Barbus barbus; Ovidio and Philippart, 2002), but this generally corresponds to precise homing to the river area exploited before spawning. Here, this was not the case for the nase, as they generally moved far downstream, sometimes leaving the tributaries to move into the main course of the Meuse. This behaviour may be associated with a sort of space-use strategy on the part of the species, but it can also simply correspond to free-flowing movements of weakened individuals after exhausting spawning events. The nase obviously invest a great deal of energy in reproduction and suffer a higher mortality rate afterwards (Luskova et al., 1995).
The remaining nase tracked during late spring, summer and autumn in the confluence site between the rivers Vesdre and Ourthe showed a space-use strategy characterized by alternating short-range up- and downstream movements through a well-defined deep run habitat (depth, 0.6-1.2 m; mean water velocity, 25-70 $\mathrm{cm}^{-1}$ ) and long-range movements corresponding to changing rivers (but the nase still used the same deep run habitat in the Vesdre and Ourthe). Intermediate depth use in this study can be seen as a trade-off between risk avoidance and food occurrence for a grazer fish. As was observed in the River Aare (Huber and Kirchhofer, 1998) and River Sieg (Fielenbach, 1996), the home-range size was larger in the warmer season than during the winter. Intensive tracking clearly demonstrated that nase move in shoals over long distances, as three individuals were observed migrating together from the River Vesdre to the River Ourthe. The nase shoaling mechanisms are currently unknown, except for reproductive behaviour (Prokes and Peňáz, 1978; Dedual, 1990 in Huber and Kirchhofer, 1998). Huber and Kirchhofer (1998) suggested that outside the spawning season, nase are non-territorial and aggregate at the most favourable habitats within the river. Nase adults form single-species shoals. However, juveniles and immature fish form multiple-species schools. During growth, fish may move progressively from shoals of one type of habitat to another. This illustrates that during its growth period, C. nasus uses space within an original shoal structure (Philippart, 1981) Complementarily, this study further demonstrated that, in some instances, nase move in groups of individuals from one river to another.

In conclusion, this study clearly demonstrates the important vulnerability of nase living in highly fragmented environments, as they show poor ability and/or motivation to clear the slightest physical barriers to reach potential spawning grounds 
in the upper part of the rivers. Such poor ability to clear physical obstacles by different cyprinids species was also suggested by recent telemetry studies (Geeraerts et al., 2007; Horký et al., 2007; Ovidio et al., 2007a) and contrasted with the largely higher capacities of brown trout Salmo trutta and European grayling Thymallus thymallus to clear similar barriers (Ovidio et al., 2007b). Such results reveal the importance with the highest priority to consider the restoration of free movements of rheophilic cyprinids in fragmented environments.

\section{Acknowledgements}

This research is part of the 'Obstruction to Fish Migration' project, which receives financial support from the Ministry of Natural Resources and Environment (D.G.R.N.E.) of Wallonia, Belgium, represented by F. Lambot and P. Orban. J.C. Philippart is a Research Associate from the Belgian 'Fonds National de la Recherche Scientifique'. The authors thank Gilles Rimbaud, Yvan Neus, Damien Sonny, Cécile Gilles, Christophe Korzack, Déborah Otte and Audrey De Wespin for field support and two anonymous referees for constructive comments. Linda Northrup (English solutions) provided English corrections.

\section{References}

Bauer, C.; Unfer, G.; Loupal, G., 2005: Potential problems with external trailing antenna: antenna migration and ingrowth of epithelial tissue, a case study from a recaptured Chondrostoma nasus. J. Fish Biol. 67, 885-889.

Dedual, M., 1990: Biologie et problèmes de dynamique de population du nase (Chondrostoma nasus) dans la Petite Sarine. PhD thesis. Univ. Fribourg, Fribourg, Switzerland, 159 pp.

Fielenbach, J., 1996: Zeitliche und räumliche Verteilungsmuster des nase Chondrostoma nasus (L.) in der Sieg. Diplomarbeit Friedrich-Wilhelms-Universität Bonn. Bonn, Germany, 112 pp.

Geeraerts, C.; Ovidio, M.; Verbiest, H.; Buysse, D.; Coeck, J.; Belpaire, C.; Philippart, J. C., 2007: Mobility of individual roach Rutilus rutilus (L.) in three weir-fragmented Belgian rivers. Hydrobiologia 582, 143-153.

Guillaume, N., 2006: Etude de l'influence de la centrale de Heid de Goreux sur la morphologie de l'Amblève et sur l'utilisation de l'habitat physique par des poissons rhéophiles entre Nonceveux et Sougné-Remouchamps. Ms Thesis in Geographical Sciences, University of Liège, Liège, Belgium.

Horký, P.; Slavík, O.; Bartoš, L.; Kolářová, J.; Randák, T., 2007: Behavioural pattern in cyprinid fish below a weir as detected by radio telemetry. J. Appl. Ichthyol. 23, 679-683.

Huber, M.; Kirchhofer, A., 1998: Radio telemetry as a tool to study habitat use of nase (Chondrostoma nasus L.) in medium sized rivers. Hydrobiologia 372, 309-319.

Huet, M., 1949: Aperçu de la relation entre la pente et les populations piscicoles des eaux courantes. Schweiz. Z. Hydrol. 11, 332-351.

Jepsen, N.; Koed, A.; Thorstad, E. B.; Baras, E., 2002: Surgical implantation of telemetry transmitters in fish: how much have we learned? Hydrobiologia 483, 239-248.

Keckeis, H.; Frankiewicz, P.; Schiemr, F., 1996: The importance of inshore areas for spawning nase Chondrostoma nasus (Cyprinidae) in a free-flowing section of a large river (Danube, Austria). In The ecology of large rivers. Archiv. Hydrobiol. D. W. Sutcliffe (Ed.). 10 (Suppl. 113), 51-64.

Lampert, W.; Link, W., 1971: Tagging experiments and count of ascending fish at upper Rhine dams in 1947 and 1952. Arch. Hydrobiol. 38, 315-335.
Lelek, A.; Peňáz, M., 1963: Spawning of Chondrostoma nasus (L.) in the Brumokva River. Folia Zool. 12, 121-134.

Lusk, S., 1967: Population dynamics of Chondrostoma nasus (Linneaus, 1758 ) in the Rokytna River. Acta. Sc. Nat. Brno 1, 473-522.

Lusk, S.; Hanel, L.; Luskova, W., 2004: Red List of the ichthyofauna of the Czech Republic: Development and present status. Folia Zool. 53, 215-226.

Luskova, V. S.; Lusk, S.; Halacka, K., 1995: Yearly dynamics of enzyme activities and metabolite concentrations in blood plasma of Chondrostoma nasus. Folia Zool. 44, 75-82.

Mann, R. H. K.; Penczak, T., 1986: Fish production in rivers: a review. Pol. Arch. Hydrobiol. 33, 233-247.

Mellas, E. J.; Haynes, J. M., 1985: Swimming performance and behaviour of rainbow trout (salmo gairdneri) and white perch (Morone americana): effects of attaching telemetry transmitters. Can. J. Fish. Aquat. Sci. 42, 488-493.

Mercier, P., 2001: Etude comparée de la mobilité circum-reproduction de deux cyprinidés rhéophiles, le hotu (Chondrostoma nasus) et le chevaine (Leuciscus cephalus) dans la Meuse liégeoise à continuité fluviale restaurée. Ms Thesis in Zoological Sciences, University of Liège, Tihange, Belgium.

Nelva, A., 1997: La penetration du hotu, Chondrostoma nasus (poisson Cyprinidé), dans le réseau hydrographique français et ses conséquences. Bull. Fr. Peche Piscic. 344/345, 253-269.

Ovidio, M.; Philippart, J. C., 2002: The impact of small physical obstacles on upstream movement of six species of fish (Synthesis of a year telemetry study in the River Meuse basin). Hydrobiologia 483, 55-69.

Ovidio, M.; Baras, E.; Goffaux, D.; Birtles, C.; Philippart, J. C., 1998: Environmental unpredictability rules the autumn migrations of trout (Salmo trutta) in the Belgian Ardennes. Hydrobiologia 372, 262-273.

Ovidio, M.; Parkinson, D.; Philippart, J. C.; Baras, E., 2007a: Multiyear homing and fidelity to residence areas by individual barbel (Barbus barbus). Belg. J. Zool. 137, 183-190.

Ovidio, M.; Capra, H.; Philippart, J. C., 2007b: Field protocol for assessing small obstacles to migration of brown trout Salmo trutta, and European grayling Thymallus thymallus: a contribution to the management of free movement in rivers. Fish. Manag. Ecol. 14, 41-50.

Peňáz, M., 1996: Chondrostoma nasus-its reproduction strategy and possible reasons for a widely observed population decline-a review. In: Conservation of endangered freshwater fish in Europe. A. Kirchhofer and D. Hefti (Eds). Birkhäuser Verlag, Basel, Switzerland, pp. 278-285.

Philippart, J. C., 1981: Démographie du hotu, Chondrostoma nasus (Linné) (Teleostai: Cyprinidae) dans l'Ourthe (Bassin de la Meuse, Belgique). Ann. Soc. R. Zool. Belg. 110, 199-219.

Povz, M., 1988: Migration of the nase carps (Chondrostoma nasus L.1758) in the River Sava. J. Aquat. Prod. 2, 149-163.

Prokes, M.; Barus, V., 1995: Surviving fragments of a Chondrostoma nasus population under extreme conditions in the Mohelno reservoir (Czech republic). Folia Zool. 44, 63-67.

Prokes, M.; Peňáz, M., 1978: The course of spawning, early development and longitudinal growth of the nase carp, Chondrostoma nasus, in the Rokytna and Jihlava rivers. Folia Zool. 27, 269-278.

Winter, J. D., 1983: Underwater biotelemetry. In: Fisheries techniques. L. A. Nielsen and D. L. Johnson (Eds). American Fisheries Society, Bethesda, MD, pp. 371-395.

Zbinden, S.; Maier, K. J., 1996: Contribution to the knowledge of the distribution and spawning grounds of Chondrostoma nasus (Pisces, Cyprinidae) in Switzerland. In: Conservation of endangered freshwater fish in Europe. A. Kirchhofer and D. Hefti (Eds). Birkhäuser, Verlag, Basel, Switzerland, pp. 287-297.

Author's address: Michaël Ovidio, Biology of Behaviour Unit, Laboratory of Fish Demography and Hydroecology, University of Liège, 10, Chemin de la Justice, B-4500 Tihange, Belgium.

E-mail: m.ovidio@ulg.ac.be 